\title{
CORPORATE SOCIAL RESPONSIBILITY AS INSTITUTIONAL HYBRIDS
}

\author{
Eva Boxenbaum \\ Copenhagen Business School \\ Copenhagen, Denmark
}

\begin{abstract}
This paper empirically examines the impact of societal context on constructs of corporate social responsibility (CSR). The empirical analysis is informed by neo-institutional theory, which conceptualizes CSR constructs as potential or actual institutions. A case study from the Danish business setting identifies the steps that a project group of business actors took to develop a new CSR construct. The steps include the transfer and translation of a foreign institution in response to a field-level problem, major events, and partial deinstitutionalization of an established CSR construct. The findings suggest that the new CSR construct is an institutional hybrid, a combination of foreign and familiar institutions that make a new CSR construct innovative, legitimate, and continuous with existing practice in the business setting. The paper proposes that CSR constructs are malleable institutional hybrids that are most easily implemented if tailored to the social context. It concludes with implications for managers who want to select, design and implement CSR constructs in their own business settings.
\end{abstract}

\section{The Global Compact}

In an address to The World Economic Forum on 31 January 1999, United Nation Secretary-General Kofi Annan challenged business leaders to join an international initiative - the Global Compact - that would bring companies together with UN agencies, labour and civil society to support nine (now ten) principles in the areas of human rights, labour, the environment, and anti-corruption.

The Global Compact's ten principles in the areas of human rights, labour, the environment and anti-corruption enjoy universal consensus and are derived from 'The Universal Declaration of Human Rights,' 'The International Labour Organization's Declaration on Fundamental Principles and Rights at Work,' 'The Rio Declaration on Environment and Development, and 'The United Nations Convention Against Corruption.'

The Global Compact is now entering its next stage of development - from a phase of entrepreneurial growth to one of increasing organizational maturity. With a network of nearly 2,000 companies and other 
stakeholders, operating in more than 70 countries, the Global Compact is ready to move to a new level of performance.

In December 2004, the first draft of a White Paper proposing a new business model and governance structure will be shared with governments, businesses, labour and civil society groups, and other stakeholders, for review, comment and input. In September 2005, The Global Compact Office will begin to implement the new business model and governance structure.

(Extracts, www.unglobalcompact.org, November 18, 2004)

This paper addresses the process through which a new CSR construct comes into existence and, in particular, the role of social context in this construction process. The Global Compact exemplifies one such construct of corporate social responsibility (CSR). A CSR construct is a form of CSR that is specific enough to be implemented in practice. The Global Compact is a unique construct in that it draws exclusively on international conventions. It defines CSR as universally as possible to make the construct relevant and appealing across the globe. The Global Compact also exemplifies a CSR construct that has been successful in its ambition of spreading rapidly across the world. Not all CSR constructs make it this far, or this fast. Some never diffuse beyond the innovative setting, others vanish like yesterday's fads and fashions. Yet others are never intended for global diffusion, targeting instead implementation at a more modest scale.

There are many different CSR constructs, some of which are local or national in scope, while others are more international in orientation. A close look reveals that they draw on quite different elements and traditions in their CSR definitions. These differences can manifest themselves in divergent CSR practices across nations. For instance, socially responsible investment and philanthropy are most widespread in United States, while formal reporting on social and environmental performance is only obligatory in France. In United Kingdom, pension funds are obliged to make their investment criteria transparent, while Denmark has made legal and administrative provisions to optimize socially responsible human resource management. Empirical research confirms that there are national variations in CSR constructs (Maignan \& Ralston, 2002), and that CSR constructs therefore do not travel easily across societal boundaries (Rowley \& Berman, 2000).

There is widespread acknowledgement that CSR can take various forms in practice. As a result, much effort has been devoted to develop typologies and taxonomies for CSR (e.g., Carroll, 1979; Wood, 1991; Clarkson, 1995; Commission of the European Communities, 2001; Roberts, 2003). None of these frameworks apparently enjoy widespread consensus. Interestingly, despite the efforts devoted to defining CSR, this notion is surrounded by much the same ambiguity today as it was 30 years ago (see Sethi, 1975). In recent years, scholars have increasingly abandoned the quest for a normative CSR theory and a universal CSR definition. Instead, they have turned their attention to the contextual features of CSR, calling for a better understanding of the institutional processes that shape the creation, 
utilization, and change of CSR (Rowley \& Berman, 2000:415). The present paper responds to this call in empirically investigating the institutional processes that lead to the generation of new CSR constructs.

Previous CSR research offers little insight into the factors that make CSR constructs vary across societal context. Some suggest that empirical research is excessively difficult to conduct without a solid theoretical platform for CSR (U11man, 1985; Mitnick, 1993; Rowley \& Berman, 2000). An alternative perspective may be that the very pursuit of a unique CSR theory is a mistake in the first place. A more general theory, which applies to CSR yet also extends far beyond it, may be very useful for an empirical analysis. Neo-institutional theory is a promising theory for such an undertaking. It conceptualizes CSR constructs as potential institutions, i.e., beliefs and practices that are closely associated with CSR in a given societal context. Neo-institutional theory thus offers insight into the convergence of CSR within nations and the divergence across nations, without discounting the possibility of global diffusion (see, e.g., Kostova \& Roth, 2002). In recent years, neo-institutionalists have addressed the micro-processes that lead to the emergence of new institutions. This insight is applied in the present paper to investigate the making of a new CSR construct in its societal context.

The first section of the paper outlines neo-institutional theory in relation to CSR, while the second section describes the analytical framework and methodology. In the third section, a case study from the Danish business setting shows how a group of business actors developed a new CSR construct in response to the societal context. The paper concludes with a discussion that emphasizes the managerial implications of the research findings.

\section{CSR and Neo-Institutional Theory}

Neo-institutional theory conceptualizes CSR constructs as institutions or potential institutions. A CSR construct is an institution if it is taken for granted and perceived as a universal definition of CSR in a given societal context. It is a potential institution if it is seen as one among other plausible definitions of CSR. A CSR construct must diffuse widely before it comes to be a potential institution. At the initial steps of diffusion, it is but a proto-institution. Proto-institutions are "new practices, rules and technologies that transcend a particular collaborative relationship and may become new institutions if they diffuse sufficiently" (Lawrence, Hardy \& Phillips, 2002: 281). Proto-institutions are thus new constructs that diffuse beyond the innovative setting. This initial diffusion is most likely to occur if the new construct is designed for diffusion purposes (Hargadon \& Douglas, 2001) and if the innovators are highly engaged in inter-organizational collaboration and highly embedded in the societal context (Lawrence, Hardy \& Phillips, 2002). Neo-institutional theorists are still struggling to explain the micro-dynamics of the construction process itself. At present, there are multiple proposals as to the making of a new construct - before it diffuses and is enacted in other settings. 
The Global Compact is an example of a construct that first became a proto-institution and then a potential institution. Few other CSR constructs have diffused as widely as the Global Compact, yet many CSR proto-institutions certainly exist at various national or regional levels of the world. Presumably, only few of these proto-institutions will diffuse far beyond their innovative setting and become institutions. Most will probably fade away or reside the space to other CSR constructs. To become an institution at the global level, the Global Compact must come to be perceived around the world as the natural form of CSR.

Institutions are the forces that exert pressure on firms to adopt similar CSR constructs to other firms in the same societal context. Neo-institutional theory operates with three types of institutions. Cognitive institutions are the worldview, the collective beliefs about the social world, or, more precisely, the causal relations believed to guide social interaction (Dobbin, 1994). Normative institutions are the collective norms that determine appropriate behaviour, that designate which goals are valuable to pursue and how to legitimately pursue them (Scott, 1987, 1994). Regulative institutions are the formal rules and regulations that carry formal sanctions if violated, e.g., laws. The three types of institutions overlap considerably with one another, but are rarely fully separable in practice (Scott, 2001). They tend to reinforce one another, although there are many exceptions. For instance, norms may differ from the law, just as a norm may persist after the abandonment of the corresponding belief.

Institutions form at various levels of society. In theoretical formulations, institutions form inside an organizational field. An organizational field is the primary social environment of a firm: it may be an industry or a nation (DiMaggio \& Powell, 1991) or a collection of firms interested in the same topic (Hoffman, 1999). "The notion of field connotes the existence of a community of organizations that partakes of a common meaning system, and whose participants interact more frequently and fatefully with one another than with actors outside the field" (Scott, 1994: 207-8). Since firms in the same organizational field are subjected to the same institutions, they tend to adopt similar structures and practices (Fligstein, 1991). They do so to obtain legitimacy, which is required to survive on the market (DiMaggio \& Powell, 1983).

\section{Analytical Framework}

The analytical framework draws on a recent process model of institutional change (Greenwood, Suddaby \& Hinings, 2002). The model proposes that new institutions emerge through six consecutive steps: 1) precipitating jolts, 2) deinstitutionalization, 3) preinstitutionalization, 4) theorization, 5) diffusion, and 6) reinstitutionalization (alternatively fading away as fads and fashion). The third step, preinstitutionalization, is when a new construct takes initial form, before theorization refines and generalizes it so as to optimize diffusion. Preinstitutionalization occurs when organizations make independent innovation as they try to find solutions to perceived problems (ibid: 60 ). 
The mechanisms of institutional innovation, of preinstitutionalization, consist in path-dependency and diffusion (Campbell, 2004, chap. 3). These two mechanisms are embodied in the notion of translation. Translation is the process through which an institution is modified as it diffuses from one field to another (Czarniawska \& Joerges, 1996; Djelic, 1998; Lippi, 2000). The purpose of modification is to fit the foreign institution to the receiving field, making it recognizable in this setting (Campbell, 2004; Hargadon \& Douglas, 2001; Kostova \& Roth, 2002; Lippi, 2000), and meeting the interests of adopters (Zeitlin, 2000; Pieterse, 1994). If perceived as superior to existing forms in the field, the translated form optimizes chances of adoption, which is a precondition for impacting on the receiving field (Djelic, 1998).

Before being translated, foreign institutions diffuse in the form of novel practices. Practices are templates for action, scripts that guide the behavior of actors (Barley \& Tolbert, 1997). These behavioural templates boil down to cognitive frames. Cognitive frames have a powerful effect on behaviour exactly because they are taken for granted. They operate as background structures and are rarely subjected to scrutiny, simply because they are not seen as options and choices. Frames exercise hegemonic power when they position some actors better than others without being recognized for having this function (Lukes, 1974). Cognitive frames are a component of cognitive and normative institutions in as much as they capture the dominant worldview and norms of field members. They can take the form of causal relations, that is, as means-end frames that field members implicitly believe to be universally true and appropriate (Dobbin, 1994; Scott, 2001).

\section{Methodology}

The aim of the empirical analysis is to illuminate the process through which a new CSR construct comes into being. According to the analytical framework above, new CSR constructs are local modifications of foreign institutions. The objective is to trace and outline this modification process, using a case study from a Danish business setting. This case study represents a deliberate example of CSR construction. Not all new CSR constructs emerge in such a deliberate, explicit fashion. An explicit case is useful to the extent that it illuminates construction processes that apply to less explicit cases as well. Construction processes are best illuminated in a real-time study, one that permits direct observation of microdynamic processes. A real-time study of CSR construction processes must, of course, be conducted long before it is known whether a new CSR construct will become an institution or fade away as yesterdays' fads and fashion. The general construction processes should be similar in either case.

The case study is a partnership between two large firms in the Danish service industry. The partnership is a project group composed of about 10 business actors, which are associated directly or indirectly with the departments of human resource management in one of the two participating firms. The project group designed and implemented new managerial practices relating to CSR and diversity management in the two participating firms. Their initial meetings resulted in 
a formal funding application to the European Union (EU). The project received funding for three years, which took the form of 50/50 cost sharing between the EU and the participating firms.

I collected real-time data in 2002 during the conceptual phase of the project. Data collection spanned about eight months and covered the period when the new CSR construct was developed in such detail that implementation was made feasible. Data collection consisted in observing project group meetings as a nonparticipant observer, conducting individual interviews with ten key members of the group, and collecting written material used or produced during this phase of the project. I collected supplementary data at the field level to identify the institutions in play during reconstruction. The organizational field is Denmark in as much as the two firms and the participating business actors oriented themselves primarily to the national context when discussing CSR. Field level data consisted in keyword searches in a national newspaper database (Infomedia), an online governmental database (www.folketinget.dk), and relevant ministerial websites. The keywords were drawn from non-participant observation of project group meetings and individual interviews.

The unit of analysis is the mean-ends frame. As discussed previously, meansend frames are implicit causality structures that guide practices and make them socially meaningful. Institutionalized means-end frames are standard templates for action in an organizational field; they are core features of cognitive and normative institutions. Established means-end frames remain institutionalized as long as field members continue to reproduce them without reflection, that is, without consideration of alternatives (Dobbin, 1994; Zucker, 1988). For a CSR construct to be new, it must draw upon a means-end frame that differs from the established means-end frame in relevant domains of practice. The empirical question is thus how the ten business actors developed a new means-end frame for CSR, one that differed from the governmental CSR construct that was already institutionalized in the field.

The analytical procedures, assisted by the qualitative software program Atlas.ti, consisted in identifying means-end frames in the data material, both institutionalized and novel means-end frames. To identify the institutionalized ones, I triangulated data from the project group level (interviews, observations, texts) with data from the field level (texts). This procedure resulted in a set of institutionalized means-end frames that represent the relevant cognitive and normative institutions in the field. These frames were the ones that field members apparently agreed to be true and appropriate for human resource management practice. To identify novel means-end frames, I singled out means-end frames that interviewees implicitly brought up when describing the novel CSR construct. Means-end frames were registered as novel only if they differed significantly from the means-end frame of the governmental CSR construct, significantly referring to the end of such frames. The novel means-end frames were singled out for open-ended analysis to trace their origin and trajectory into the mindscape of actors. 


\section{Results: The Making of a New CSR Construct}

This section outlines how the ten business actors developed a new CSR construct with path-dependency to the governmental CSR construct. It presents the process of preinstitutionalization as it applies to one case of CSR construction. The new CSR construct came about as actors adopted a foreign practice, diversity management, and merged it with the practices flowing from the governmental CSR construct. The resulting construct became a CSR proto-institution as it diffused into the two participating firms and to Danish society more broadly. Space does not permit due attention to the subsequent diffusion process. The case study focuses on the construction process, and provides a preamble to contextually situate this process. The preamble introduces the governmental CSR construct and two precipitating jolts that led to partial deinstitutionalization of this construct. The central part outlines the innovative construction process that followed in the project group as the new CSR construct was developed.

\section{Preamble: Precipitating jolts and deinstitutionalization}

In 2002, this national context was one of growing reflection on a well-established governmental CSR construct. This governmental CSR construct had developed in 1994 as part of a CSR campaign launched by the Social Democratic government of Denmark. The campaign was a reponse to demographic projections that predicted relatively more elderly people, immigrants, and single-parent families in the Danish population. This demographic composition would increase the demand on public finances and jeopardize the economic foundation of the Danish welfare state, making the state unable to offer the 1994 level of public services in 2010 (Ministry of Labour et al., 2001: 8). To circumvent this turn of events, the Social Demographic government faced an imperative to intervene. It opted to activate more passive income recipients and launched the CSR campaign. The campaign encouraged firms to integrate and retain more people in the active labour force, the principal target groups being immigrants, refugees, the physically challenged, and people with a temporarily reduced working capacity. Through CSR, firms would contribute to protecting the future of the Danish welfare state.

The CSR campaign, which ran until 2002, underscored firms' moral duty to participate in reaching collective goals. The government assigned the primary responsibility for employee retention to firms (Ministry of Labour et al., 2001: 10) and requested firms to act in the collective interests of the nation, not expecting to derive financial benefits from every act of inclusion and responsibility (ibid: 21). In return, the government subsidized firms that hired or retained employees with low working capacity (Flex Jobs), rewarded the best firms with prizes, and developed a certification system (The Social Index) to enable firms to brand themselves on good CSR performance (www.detsocialeindeks.dk). It made legal adjustments to improve the interfaces between labour unions, private firms, and municipal authorities so as to remove administrative barriers that could discourage firms from acting responsibly (Social Partnerships). In short, the government 
Vol. 23, No. 1

developed an elaborate administrative structure and set of new practices relating to corporate social responsibility.

The governmental CSR campaign promoted the means-end frame in Figure 1. It stipulates that optimal workforce integration and retention (the means) lead to socioeconomic development of the Danish welfare state (the end). This means-end frame represents the governmental CSR construct, later to be known as well as The Inclusive Labour Force. The governmental CSR construct and its related means-end frame spread throughout the field in the second half of the 1990 s (Figure 2). It became increasingly synonymous with CSR and was widely perceived to constitute the normative essence of CSR in 2001, perhaps because of few alternative CSR constructs in the field. The governmental CSR construct was an institution.

Figure 1

Means-End Frame of Governmental CSR Construct

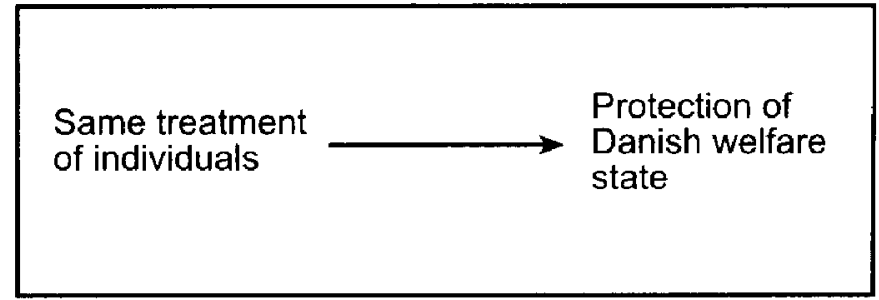

Figure 2

Keyword Search on 'Corporate Social Responsibility' in the National, Daily Newspaper of Berlingske Tidende

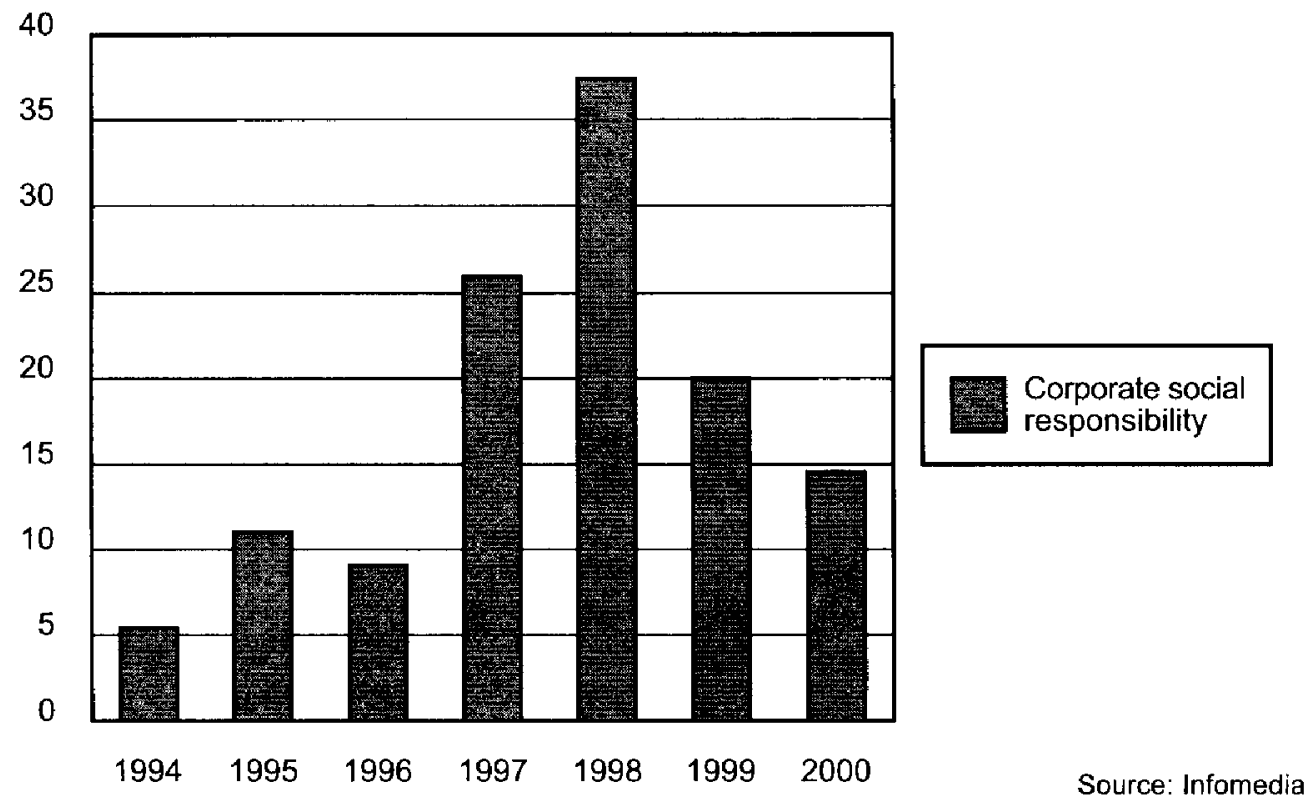


In 2001, the governmental CSR construct became subject to scrutiny and debate. The occasion was two major events, two precipitating jolts, which unsettled the taken-for-granted status of the governmental CSR construct. The first event was the Green Paper on CSR that the European Commission published in July 2001 (Commission of European Communities, 2001). This document defined CSR much broader than did the Danish government. This alternative definition gave rise to a field-level discussion of what CSR 'really' means. The Danish Parliament held a public hearing on the Green Paper and concluded that the Danish CSR construct was superior to that of the European Commission, primarily because of its more operational definition and superior tools for implementation and measurement (Europaudvalget, 2002). The choice to hold on to the governmental CSR construct indicated a high level of institutionalization (Zucker, 1991). The second event was a change of Danish government in November 2001. The Liberal Party replaced the Social Democratic Party. This change spurred a revision of social and labour policy. For instance, the primary partners of the government shifted from labour unions to private firms, and the responsibility for CSR moved from the Ministry of Social Affairs to the Ministry of Employment. These changes, fully predictable in relation to a right-wing turn of government, unsettled the governmental CSR construct and gave momentum to a process of deinstitutionalization.

Deinstitutionalization set in as it became apparent that firms were not implementing the governmental CSR construct to the extent the government had hoped. Many Danish firms, including the two firms in the case study, responded positively to the governmental CSR campaign and adopted it in their policies and formal structures. They also implemented some dimensions in practice, but were apparently reluctant to sacrifice financial performance for a better CSR performance. One visible effect was the failure in integrating immigrants and refugees into the work force. Six years into the CSR campaign, a governmental task force on the integration of immigrants concluded with dismay that "the unemployment rate of ethnic minorities is almost $17 \%$ as opposed to $5.6 \%$ in the remaining population, ... a problem that both the government and labor market partners consider very important to address" (Partsudvalget om integration, 2000: 4). It was a classic situation of firms not walking the talk. There was discrepancy between discourse and practice: firms endorsed the governmental CSR construct, but were hesitant or selective in their implementation of it. This discrepancy, also known as decoupling (Meyer \& Rowan, 1977), resulted in partial deinstitutionalization of the governmental CSR construct. This context gave favourable conditions for innovation and construction at the stage of preinstitutionalization.

\section{Preinstitutionalization}

The constitution of the project group took place in late 2001 , immediately after the two precipitating jolts and during the deinstitutionalization process. The idea to the project had taken form in the spring and summer of 2001, and the three initiators had subsequently received preliminary funding to establish a project group and elaborate a formal funding application during the winter of 
2001/2002. The initiators recruited participants from the two firms involved in the project and attached some external experts to the project as well. In starting to develop a new CSR construct, the project group immediately targeted the problem of decoupling. Their proposal was to integrate social responsibility in the core of current business strategies in the two firms (confidential document, January 2002). This, they argued, would increase the likelihood of implementation and make CSR more resistant to economic conjectures. Their goal was thus one of combining social responsibility with financial performance, a combination absent from the governmental CSR construct.

Another strategy of the project group was to target the integration of immigrants. This problem received much attention in the field at the time (see Figure 3 ), and was widely perceived as a major challenge for Danish society, much as in other fields:

Denmark is a very homogeneous society. We have only had one problem, we think, and that was gender. We have worked a lot with that, come to disagree and agree about it. But what sets a new agenda in Denmark now is the arrival of immigrants and refugees who have not been requested to come here, as were foreign workers some decades ago. We get a group of people that live regular lives here and who do not behave as guests. And that is a major challenge for us. What do we do with this? That is when ethnic integration is put on the agenda and when the real challenge begins: immigrants and refugees are from all kinds of different origins and cannot be treated in a uniform way.

(Consultant)

\section{Figure 3}

Keyword Search on "Integration and Immigrants" in the National, Daily Newspaper of Berlinske Tidende

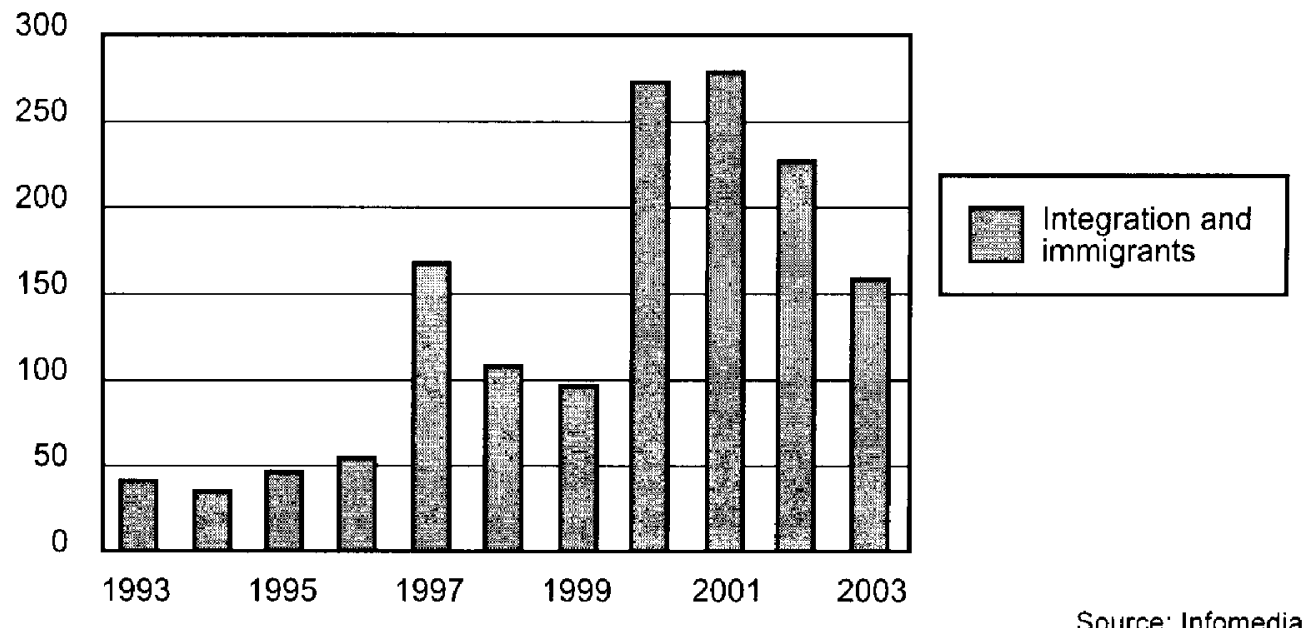


The problem in integration of immigrants, combined with the decoupling problem, assured alignment of project objectives with the objectives of the participating firms and the field of Denmark. The new Liberal government was keen to collaborate with firms on the integration of immigrants, and the two firms were interested in optimizing their CSR performance. This alignment of objectives helped mobilize resources to the project. The two firms engaged in a 50/50 cost sharing agreement with a European Union Fund, administered through the Danish government, for a period of three years.

Besides aligning objectives and generating resources, the project group worked intensively on turning their idea into a practice format. Their idea was to adopt a North American practice that had proved itself superior in integrating immigrants, relative to the Danish governmental CSR construct. The inspiration came from North American working experience:

Two years ago, in the summer of 2000 , I move back to Denmark [after five years in United States]. I get a shock when I return to Denmark because the debate on immigrants and refugees has become quite hateful and nasty. Now I have been in a country, United States, where it is common to work with turning these sentiments of aggression and anger into something constructive. It was not very pleasant to return to this narrow-minded, condescending debate in Denmark. So you can say, I come home to a country that has not at all worked with these problems, and I come with knowledge that it is feasible to do it differently. I also know that it is possible in Canada, which is similar to Denmark in many ways. This was the 'luggage' I had when the immigration problem came up, and this luggage turned out to be quite useful.

(Consultant)

The idea came up in response to a problem experienced in Denmark, the idea originating in another field. This idea was to implement the North American practice of diversity management in Denmark. Diversity management is a human resource management practice that fosters personal development of employees while putting the skills of different individuals to optimal use for the firm (Thomas \& Ely, 1996; Kelly \& Dobbin, 1998). Diversity management is thus a win-win strategy that integrates financial and personal development goals. Figure 4 shows the means-end frame that underpins this concept and its related practices. The practice is targeted at socially marginalized groups, that is, individuals with skills and potential hidden behind structural barriers of discrimination. Immigrants and refugees belong to the target group, as do women with managerial potential, homosexuals, religious minorities, etc. Diversity management appealed to the project group for two reasons: it promised to be a superior solution to the integration of immigrants, and it simultaneously minimized the decoupling between discourse and practice because it aligned better with financial performance indicators than did the governmental CSR construct. The project group adopted this foreign institution and proceeded to plan the implementation of it in the two Danish firms. 
Figure 4

Means-End Frame of Diversity Management

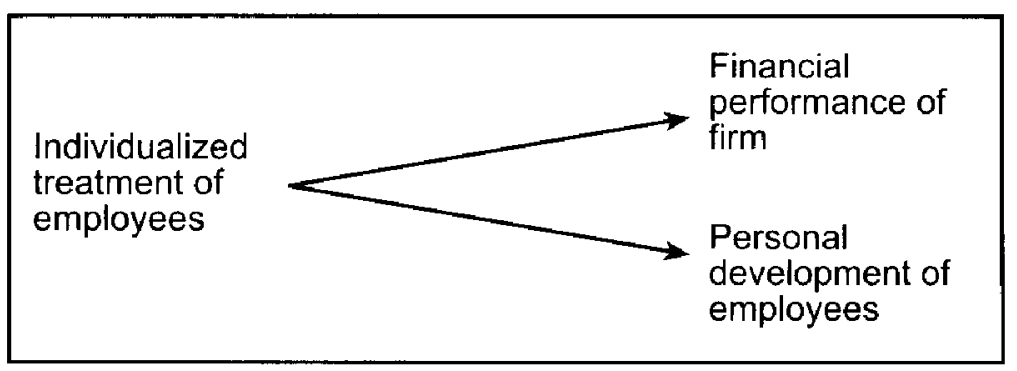

As the project group investigated the options of implementation, it became clear that its means-end frame collides with institutions in the field. The end of profit generation is illegitimate in the field in as much as it is incompatible with the normative institution of distributing financial resources as equally as possible. Though profit generation is acceptable in the sense of helping firms survive, it should be a means to an end, not an end in itself. It certainly is inappropriate as the primary motivation for engaging in a socially oriented practice like CSR:

I can feel that Danish managers prefer social responsibility to the bottom line. In Denmark we do not like this concept of the bottom line, of making money. We have this equalizing society that pulls the bottom up, and the top down. It is extremely equalizing. Nowhere in the world do you find better or worse. It is not so nice for poor people that others make money; so do not speak too loudly about it, okay.

(Consultant)

The end of profit generation, contained in the means-end frame of diversity management, is thus incompatible with the normative institution of equalization. In fact, the means is equally at odds with this normative institution. Individualized treatment of employees violates the norm of treating people as equally as possible:

Diversity management is interpreted differently in Denmark than it is in England, where it is legitimate to make categories that are based on terms that we tend to find discriminating, such as whites and blacks. In England, there is more open recognition of the fact that people are different and people talk more freely about the differences. In a Danish context, where we are used to a homogenous society, it is rather appalling to mention the fact that people are different. It can have negative consequences because if you cannot talk about people being different, then you also cannot talk about treating them differently. I think that the Danish tendency to equalize and homogenize is, in fact, an obstacle to diversity management and individual differences. In Denmark, we see it as a matter of fairness to treat people equally. We are trained to equalize. 
The quote clearly indicates the inappropriateness of treating employees in an individualized manner. Hence, the means-end frame of diversity management is significantly at odds with a core value in the receiving field, namely the normative institution of equalization. This collision made chances slim that diversity management could successfully be implemented in the two firms, let alone diffuse within the field.

To optimize the implementation and diffusion of the imported means-end frame, the project group translated it. They first softened the means and the end to remove their negative connotations. When that procedure turned out to be insufficient for gathering support in the two firms, the project group combined the foreign institution with the governmental CSR construct, which carried legitimacy in the field. This combination was a deliberate attempt to facilitate the implementation of diversity management:

Social responsibility carries great symbolic value in Denmark. Diversity management is about working with differences, but in Denmark that stirs a reaction of "oh no, we don't want that." Our conviction is that there is no real conflict in incorporating social responsibility under diversity management. Social responsibility adds symbolic value because it is already present. We also use it because the firm had begun to work more seriously with social responsibility. When diversity management is connected to that, it makes sense to people.

(Consultant)

The project group thus utilized the governmental CSR construct to help the foreign institution of diversity management bypass a normative institution in the field. The governmental CSR construct legitimized the foreign institution, and simultaneously established continuity to current practices and administrative structures in the firms. Both features facilitated the implementation of diversity management in the two Danish firms.

At the level of practice, the two practices were combined through an overlap in their target groups. Both targeted socially marginalized groups, not necessarily identical ones, but nevertheless target groups with a sufficient overlap between them. The project proposed to integrate immigrants, physically challenged, and troubled youth, and to develop women's managerial potential. This mixed target group allowed for an overlap in practice.

The overlap also occurred conceptually. A new CSR construct emerged as the project group combined the means-end frames of the two original institutions from respectively North America and Denmark. The combination resulted in a novel means, individualized treatment of employees, and the combined ends of the original frames. The new CSR construct is thus an institutional hybrid, a combined means-end frame with multiple ends (see Figure 5). It confines CSR practices to the individualized treatment of employees in such a way as to target all three ends simultaneously. An example could be the profit-seeking skill development of unemployed immigrants. This institutional hybrid is the new CSR construct, 
generated through diffusion and path dependency in response to precipitating jolts and deinstitutionalization.

\section{Figure 5}

\section{Means-End Frame of CSR Reconstruction}

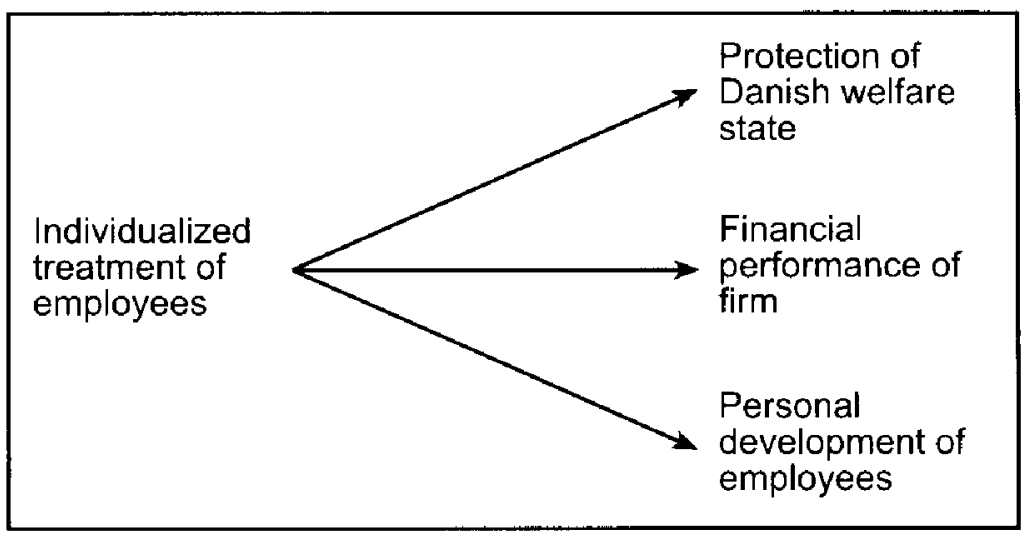

\section{Conclusion}

The case study illustrated how a group of Danish business actors developed a new CSR construct. In short, they selected a foreign institution, the North American institution of diversity management, and transferred it to the field of Denmark. They then translated it to bypass the normative institution of equalization in the receiving field, which provided a significant barrier to implementation and diffusion. The translation consisted in a combination with a legitimate institution, namely the governmental CSR construct, developed and institutionalized under the Social Democratic government in the period 1994-2001. The means-end frames of both institutions were combined, resulting in a new CSR construct that was novel and continuous with existing practice. This new CSR construct eventually appealed to the participating firms and the field more broadly, and became a proto-institution as it diffused beyond the innovative setting. The present paper focused on the construction process, leaving aside the subsequent diffusion process. In theoretical terms, the construction process occurred during the pre-institutionalization stage of institutional change (Greenwood, Suddaby \& Hinings, 2002), and evoked the two mechanisms of diffusion and path-dependency (Campbell, 2004).

At a general level, the case study findings suggest that CSR constructs are eclectic constructs. They are apparently combinations of heterogeneous institutions, built from heterogeneous means-end frames. As such, CSR constructs may be institutional hybrids. This conclusion resonates with previous research that suggest foreign institutions to be adopted and adapted selectively to suit local economic and institutional circumstances (Zeitlin, 2000), and to be recombined with other institutions to generate new practices (Rowe \& Shelling, 1991; Pieterse, 1994). 
The institutional building blocks appear to be both foreign and familiar institutions, selected for their perceived superiority in solving a problem, alternatively for their strong symbolic value in the field. Both components may well be required for new CSR constructs to appear at once novel and legitimate in a field.

Striking a balance between novelty and familiarity may be a general feature of innovative constructs that diffuse successfully. For instance, a technical innovation like Edison's electric light only diffused when the familiar institution of gas lighting was partially incorporated into the innovative construct of electric lighting (Hargadon \& Douglas, 2001). The role of the familiar institution is that of skeumorphs, which are "elements of a design that serve no objectively functional purpose but are essential to the public's understanding of the relationship between innovations and the objects they replace (Basalla, 1988)" (ibid: 491). Skeumorphs make an innovation meaningful to field members, and allow it to diffuse in a field. A contemporary example of a skeumorph is the garbage can icon on computer screens, which makes files similar to paper. In the present case study, the governmental CSR construct became a skeumorph in the new CSR construct in as much as it made diversity management meaningful to field members. Diversity management was also novel: it was sufficiently foreign to make the new CSR construct significantly different from the familiar institution of the governmental CSR construct. The new CSR construct apparently stroke this balance between novelty and familiarity, making it possible for it to diffuse as a novel construct in the field.

As institutional hybrids, CSR constructs are also malleable entities that can be rebuilt to fit new contexts and fields. Actors may replace institutional components in an existing construct or add new components to it as they see fit. New CSR constructs are perhaps most malleable in their embryonic stage, growing more robust as they are institutionalized through the subsequent steps of theorization and diffusion (Greenwood, Suddaby \& Hinings, 2002). During preinstitutionalization, CSR is apparently constructed in response to a societal context. In the case study, the societal context was one of preoccupation with the integration of immigrants in the Danish work force and partial deinstitutionalization of a governmental CSR construct. This societal context resulted in a new CSR construct that was tailored to this particular field, at this particular point in time. Despite it being tailored, the new CSR construct certainly contain elements of relevance to other societal contexts, elements that may inspire actors in other fields to adopt and modify it to fit their own societal context.

The research findings may certainly be used for prescriptive purposes. Managers may use them to design new CSR constructs that have good chances of being implemented in their own firms and of diffusing in their organizational fields. For instance, managers may begin by identifying the organizational field, i.e., the grouping of firms and organizations to which they feel kinship. For a multinational corporation, it may be other multinational firms, while an SME with historical roots in a local community may identify most with other firms in the local region or the nation. The manager may proceed by identifying a shared 
preoccupation, for instance a tenacious social problem that affect the firm and the field, and that requires resolution. A search is then required to find a successful, institutionalized solution to a similar problem in another field. When found, this practice must be transferred to the receiving field, and perhaps translated. Translation is required if the new practice contradicts with norms and values in the field. If so, the transferred practice must be combined with a legitimate institution to facilitate implementation and diffusion. The combination is the novel and legitimate CSR construct.

Managers may wish to implement CSR even if there is no tenacious problem at hand. In that case, managers may select an existing CSR construct that fit the institutions in the field and modify it if required. In either case, it is important to keep in mind that a new CSR construct must be both novel and familiar to be implemented in practice. Ideally, it is also timely and helpful in resolving an acknowledged problem. These factors, combined, may account for the empirical observation that CSR takes different form across national contexts. Perhaps they also explain why many CSR constructs never quite make it beyond the PR room, the boardroom, or formal policies, despite the best of intentions to make a real impact on practice.

\section{References}

Carroll, A. B. (1979). A three-dimensional conceptual model of corporate performance. Academy of Management Review, 4, 497-505.

Czarniawska, B. \& Joerges, B. (1996). Travels of ideas. In B. Czarniawska \& G. Sevón (Eds.), Translating Organizational Change (pp. 13-48). Berlin: Walter de Gruyter.

Clarkson, M. B. E. (1995). A stakeholder framework for analyzing and evaluating corporate social performance. Academy of Management Review, 20, 92-117.

Commission of the European Communities (2001). Green paper. Promoting a European framework for Corporate Social Responsibility. Brussels: author. Retrieved July 18, 2001, from Europa.eu.int/comm/employment_social/soc-dial/csr/csr_index.htm

DiMaggio, P. J. (1988). Interest and agency in institutional theory. In L. Zucker (Ed.), Institutional patterns and organizations (pp. 3-22). Cambridge, MA: Ballinger.

DiMaggio, P.J. \& Powell, W.W. (1991). Introduction. In W. W. Powell, \& P.J. DiMaggio (Eds.), The new institutionalism in organizational analysis (pp. 1-40). Chicago: The University of Chicago Press.

DiMaggio, P. J. \& Powell, W. W. (1983). The iron cage revisited. Institutional isomorphism and collective rationality in organizational fields. American Sociological Review, 48 (2), 147-160. 
Djelic, M.-L. (1998). Exporting the American model: The postwar transformation of European Business. Oxford: Oxford University Press.

Djelic, M.-L. \& Quack, S. (Eds.) (2003). Globalization and institutions: Redefining the rules of the economic game. Cheltenham, UK: Edward Elgar Publishing.

Dobbin, F. (1994). Forging industrial policy. The United States, Britain, and France in the railway age. Cambridge: Cambridge University Press.

Europaudvalget (2002). Referat af fælleshøringen om grønbogen om virksomhedernes sociale ansvar. [Summary of the public hearing on the Green Paper on CSR]. Folketingsăret 2001-2002, 2. samling, Info-note I 67.

Fligstein, N. (1991). The structural transformation of American industry: An institutional account of the causes of diversification in the largest firms, 1919-1979. In W. W. Powell, \& P. J. DiMaggio (Eds.), The new institutionalism in organizational analysis (pp. 311-336). Chicago: The University of Chicago Press.

Fligstein, N. (1997). Social skill and institutional theory. American Behavioral Scientist, 40 (4), 397-405.

Greenwood, R., Suddaby, R., \& Hinings, C. R. (2002). Theorizing change: The role of professional associations in the transformation of institutionalized fields. Academy of Management Journal, 45 (I), 58-80.

Hargadon, A. B., \& Douglas, Y. (2001). When Innovations meet institutions: Edison and the design of electric light. Administrative Science Quarterly, 46, 476-501.

Hoffman, A. (1999). Institutional evolution and change: environmentalism and the U.S. chemical industry. Academy of Management Journal, 42 (4), 351-371.

Huff, A. S., \& Jenkins, M. (Eds.) (2002), Mapping strategic knowledge. London: Sage Publications.

Kelly, E. \& Dobbin, F. (1998). How affirmative action became diversity management. Employer response to anti-discrimination law, 1961-1996. American Behavioral Scientist, 41 (7), 960-984.

Kostova, T. \& Roth, K. (2002). Adoption of an organizational practice by subsidiaries of multinational corporations: Institutional and relational effects. Academy of Management Journal, 45 (1), 215-233.

Lawrence, T.B., Hardy, C., Phillips, N. (2002). Institutional effects of interorganizational collaboration: The emergence of proto-institutions. Academy of Management Journal, 45 (1), 281-291. 
Lippi, A. (2000). One theory, many practices. Institutional allomorphism in the managerialist reorganization of Italian governments. Scandinavian Journal of Management, 16, 455-477.

Lukes, S. (1974). Power: A radical view. London: Macmillan Press Ltd.

Maignan, I. \& Ralston, D. (2002). Corporate social responsibility in Europe and the U.S.: insights from businesses' self-presentations. Journal of International Business Studies, 33 (3), 497-514.

Meyer, J. \& Rowan, B. (1977). Institutionalized organizations: Formal structure as myth and ceremony. American Journal of Sociology, 83, 340-363.

Ministry of Labour, Ministry of Employment, Ministry of Internal Affairs, Ministry of Social Affairs, Ministry of Education, Ministry of Economics, Ministry of Finance. (April 2001). Brug for alle - Danmark 2010 og et mere rummeligt arbejdsmarked. [A need for everyone-Denmark 2010 and a more inclusive labour force]. Copenhagen: J. H. Schultz Grafisk A/S.

Mitnick, B. (1993). Organizing research in corporate social performance: The CSP system as core paradigm. [Paper presented as a showcase session at the Annual Meeting of the International Association for Business in Society (IABS), San Diego, CA, March 19-21, 1993].

Partsudvalget om integration (January 2000). Rapport fra partudvalget om integration om integration af indvandrere og flygtninge pa arbejdsmarkedet. [Report from the subgroup of integration on the integration of immigrants and refugees]. Copenhagen, Danish Ministry of Employment. From www.bm.dk

Pieterse, J. N. (1994). Globalization as hybridization. International Sociology, 9(2), 161-184.

Roberts, J. (2003). The manufacture of corporate social responsibility: constructing corporate sensibility. Organization, 10 (2), 249-265.

Rowe, W. \& Schelling, V. (1991). Memory and modernity. Popular culture in Latin America. London: Verso.

Rowley, T. \& Berman, S. (2000). A brand new brand of corporate social performance, Business and Society, 39 (4), 397-418.

Scott, W. R. (2001). Institutions and organizations (2nd ed.). Thousand Oaks, CA: Sage.

Scott, W. R. (1994). Conceptualizing organizational fields: linking organizations and societal systems. In U. Gerhardt, H.-U. Derlien, \& F. W. Scharpf(Eds.), Systems rationality and partial interests (pp. 203-221). Baden-Baden, Germany: Nomos-Verlag. 
Scott, W. R. (1987). The Adolescence of Institutional Theory. Administrative Science Quarterly, 32 (4), 493-509.

Seo, M. G. \& Creed, W. E. D. (2002). Institutional contradictions, praxis, and institutional change: A dialectical perspective. Academy of Management Review, 27, 222-247.

Sethi, P. S. (1975). Dimensions of corporate social performance: an analytical framework. California Management Journal, 17 (3), 58-64.

Thomas, D. A. \& Ely, R, J. (1996), Making differences matter: a new paradigm for managing diversity. Harvard Business Review, 74, 79-90.

Ullman, A. H. (1985). Data in search of a theory: a critical examination of the relationships among social performance, social disclosure, and economic performance of U.S. firms. Academy of Management Review, 10, 540-557.

Wood, D. J. (1991). Corporate social performance revisited. Academy of Management Review, 16, 691-718.

Zeitlin, J. (2000). Introduction: Americanization and its limits: Reworking US technology and management in post-war Europe and Japan. In J. Zeitlin \& G. Herrigel (Eds.), Americanization and its limits: Reworking US technology and management in postwar Europe and Japan (pp.1-52). Oxford: Oxford University Press.

Zucker, L. (1991). The role of institutionalization in cultural persistence. In W. W. Powell, \& P. J. DiMaggio (Eds.), The new institutionalism in organizational analysis (pp. 83-107). Chicago: The University of Chicago Press.

Zucker, L. (1988). Where do institutional patterns come from? Organizations as actors in social systems. In L. G. Zucker (Ed.), Institutional patterns and organizations: culture and environment (pp. 23-52). Cambridge, MA: Ballinger.

Eva Boxenbaum is Assistant Professor in the Department of Organization and Industrial Sociology at Copenhagen Business School from where she recently obtained a Ph.D. in Economics and Business Administration. She conducts research on corporate social responsibility, cross-national transfer of management practices, and micro-dynamics of translation. Her work has been published in Strategic Organization, American Behavioral Scientist, and Best Paper Proceedings of Academy of Management Annual Meeting 2005. 
